\title{
SEED GERMINATION, SEEDLING ESTABLISHMENT AND REINTRODUCTION INTO THE WILD OF THE HEMIPARASITIC MEDICINAL PLANT MONOCHASMA SAVATIERI
}

\author{
Yulu CHEN ${ }^{1,2}$, Menghan ZHANG ${ }^{1,2}$, Jaime A. TEIXEIRA DA SILVA ${ }^{3 *}$, Guohua MA $^{1^{*}}$ \\ ${ }^{1}$ Key Laboratory of Plant Resources Conservation and Sustainable Utilization, South China Botanical \\ Garden, the Chinese Academy of Sciences, Guangzhou 510650 - China \\ ${ }^{2}$ University of the Chinese Academy of Sciences, Beijing - China \\ ${ }^{3}$ P. O. Box 7, Miki-cho post office, Ikenobe 3011-2, Kagawa-ken, 761-0799 - Japan \\ *Corresponding authors. E-mail: jaimetex@yahoo.com; magh@scib.ac.cn
}

\begin{abstract}
The ecology, seed germination, seedling establishment, and reintroduction of Monochasma savatieri Franch. ex Maxim, a traditional Chinese hemiparasitic medicinal herb, were studied by focusing on the distribution, climate, soil type, flowering and seed production, co-occurring vegetation, and pollinators. The distribution range of $M$. savatieri lies between $25^{\circ} 03^{\prime}-29^{\circ} 12^{\prime} \mathrm{N}$ to $113^{\circ} 39^{\prime}-120^{\circ} 27^{\prime} \mathrm{E}$, based on our sampling. M. savatieri requires vernalization to induce flowering. Seed germination was enhanced by gibberellic acid at an optimum concentration of $500 \mu \mathrm{M}$. Other plant growth regulators, including indole-3-acetic acid and 6-benzyladenine, did not enhance seed germination. Low temperature $\left(5^{\circ} \mathrm{C}\right)$ storage was favorable to keep seed viability, which was negatively influenced by increasingly long storage periods. We also examined seedling development and transplantation to the field. Seedlings were interplanted with a moss Hypnum plumaeforme, until they developed true leaves. Developed plants were then transplanted into the wild alongside a host, Gardenia jasminoides, and $23 \%$ of the transplanted plants survived after 8 months.
\end{abstract}

Key words: distribution, host, light, plant growth regulators, seed viability, transplanting, vernalization.

\section{Introduction}

Monochasma savatieri Franch. ex Maxim (Orobanchaceae, Rhinantheae tribe) is a perennial medicinal herb with widely documented medicinal properties [YAHARA \& al. 1986; KOHDA \& al. 1989; LI \& al. 2012; LIU \& al. 2013]. Its distribution is limited to a very narrow geographic belt, namely Southeast China and Kyushu, Japan [YAMAZAKI, 1993; HONG \& al. 1998]. Phylogenetic studies indicate that M. savatieri is likely to have originated in East China and nearby regions [HONG, 1986; BENNETT \& MATHEWS, 2006]. The flora of Japan also documents that M. savatieri is likely to have been introduced from China [YAMAZAKI, 1993]. Recent years have witnessed the disappearance of wild populations of $M$. savatieri due to overexploitation and habitat destruction, so much so that it has already been listed as an endangered and threatened species in Japan (Environment Agency of Japan, 2000). An additional reason for its sensitivity to ecological changes is that M. savatieri is a hemiparasitic plant that requires a suitable host plant [ZHANG \& al. 2015]. To better understand why $M$. savatieri is only distributed in a narrow geographic belt, and to better explain its ecological sensitivity, an investigation into ecological aspects, including climate, soil type, flowering and seed production, co-occurring vegetation, and pollinators is required to assess whether these factors influence its natural growth and reproductive traits. To date, only one preliminary study exists on the germination of $M$. savatieri induced by gibberellic acid $\left(\mathrm{GA}_{3}\right)$ [YANG, 2009]. However, the conditions required for seed germination 
and seedling development in nature are not known, nor are the influence of light, plant growth regulators and seed storage time on seed germination and seed viability clear. It is also not known whether seeds can be used to establish seedlings for transplantation back into the wild to replenish natural stands. In a bid to shed light on these unknowns, the main objectives of our study were to develop a seed-to-site protocol that would allow for the successful germination of $M$. savatieri seeds, the subsequent growth of seedlings, and the effective transplantation of seedlings back into the wild following sexual propagation. This study, conducted in Southeast China, also aimed to investigate the ecology of existing wild $M$. savatieri resources, and understand its vernalization requirements.

\section{Materials and methods}

\section{Distribution of wild resources}

Wild populations of M. savatieri were investigated between 2010 and 2014. Plants were collected from 14 sites in five provinces of Southeast China (Zhejiang, Jiangxi, Fujian, Hunan and Guangdong) based on the advice and guidance of local elders in these areas (Figure 1). Geographic coordinates were estimated from Google Earth. These sites show relatively abundant populations with a density of $10-50$ mature individuals per $100 \mathrm{~m}^{2}(10 \mathrm{~m}$ $\times 10 \mathrm{~m}$ ). We focused our investigation on Jiangxi province because it is near to South China Botanical Garden (SCBG) (Figure 1O), Guangzhou, in Guangdong province. Data on the climatic conditions and geographic features of the areas studied were obtained from the China Statistical Yearbook (1996-2012). For each collection site, several habitat features, including topography, sunlight and moisture regimes, soil and vegetation type, pollinators, growth and sexual (seed) reproduction were investigated and recorded. A previous study used the same collection sites to confirm the hemiparasitic nature of M. savatieri [ZHANG \& al. 2015]. Collected plants were identified at SCBG.

\section{Natural growth and vernalization test}

To investigate flowering and sexual reproduction, living plants (including hosts) were brought back to SCBG, Guangzhou from Pan'an, Zhejiang province (Figure 1A) on October 25, 2010 and November 5, 2011, from Zherong, Fujian province (Figure 1E) on March 16, 2011, from Shihan, Ganxian county, Jiangxi province (Figure 1H) on December 20, 2012 and from Tengtian, Yongfeng county, Jiangxi province (Figure 1D) on November 29 , 2013. All plants (100 individuals/collection) were cultivated separately in plastic pots (10 $\mathrm{cm}$ high and $10 \mathrm{~cm}$ in diameter) containing loess and placed under a net-covered shelter that reduced natural light incidence by $80 \%$. Southeast China is the natural distribution zone of M. savatieri [HONG \& al. 1998], and includes a total of five provinces: Jiangsu, Zhejing, Fujian, Jiangxi and Hunan. Among them, Jiangsu, Zhejing, and Fujian belong to a subtropical monsoon climate zone that is influenced by Pacific Ocean circulation. Hunan province belongs to a mainland subtropical monsoon climate, which is affected by both East Asia monsoon circulation and cold and dry air in winter. Jiangxi province is located between Fujiang province and Hunan province, which belong to a subtropical hill and mountainous moist monsoon climate. All these areas belong to a monsoon climate and experience abundant rain in spring and summer [ZHU \& al. 2011]. Guangzhou belongs to a subtropical monsoon climate with an average temperature of $21-22^{\circ} \mathrm{C}$ and usually no frost in winter and a historically extreme minimum of $-2{ }^{\circ} \mathrm{C}$. During our test period, Guangzhou's lowest temperature was always above $0{ }^{\circ} \mathrm{C}$. In Jiangxi province, both Nanchang (Northern Jiangxi) 
Yulu CHEN \& al.

and Ganzhou (Southern Jiangxi) belong to a subtropical hill and mountainous moist monsoon climate. Nanchang's average temperature is $16-17^{\circ} \mathrm{C}$ with a historically extreme minimum of $-15^{\circ} \mathrm{C}$; Ganzhou's average temperature is $18-19^{\circ} \mathrm{C}$ with a historically extreme minimum of $-6{ }^{\circ} \mathrm{C}$, and is the southernmost point of $M$. savatieri's natural distribution in Jiangxi province (Figure $1 \mathrm{~N}$ ). In these areas, in winter, low temperatures $\left(-6\right.$ to $-10{ }^{\circ} \mathrm{C}$ ) usually last for one or two months but seldom drop below $-15^{\circ} \mathrm{C}$. In summer, high temperatures usually do not exceed $35^{\circ} \mathrm{C}$ because $M$. savatieri is distributed in mountain areas.

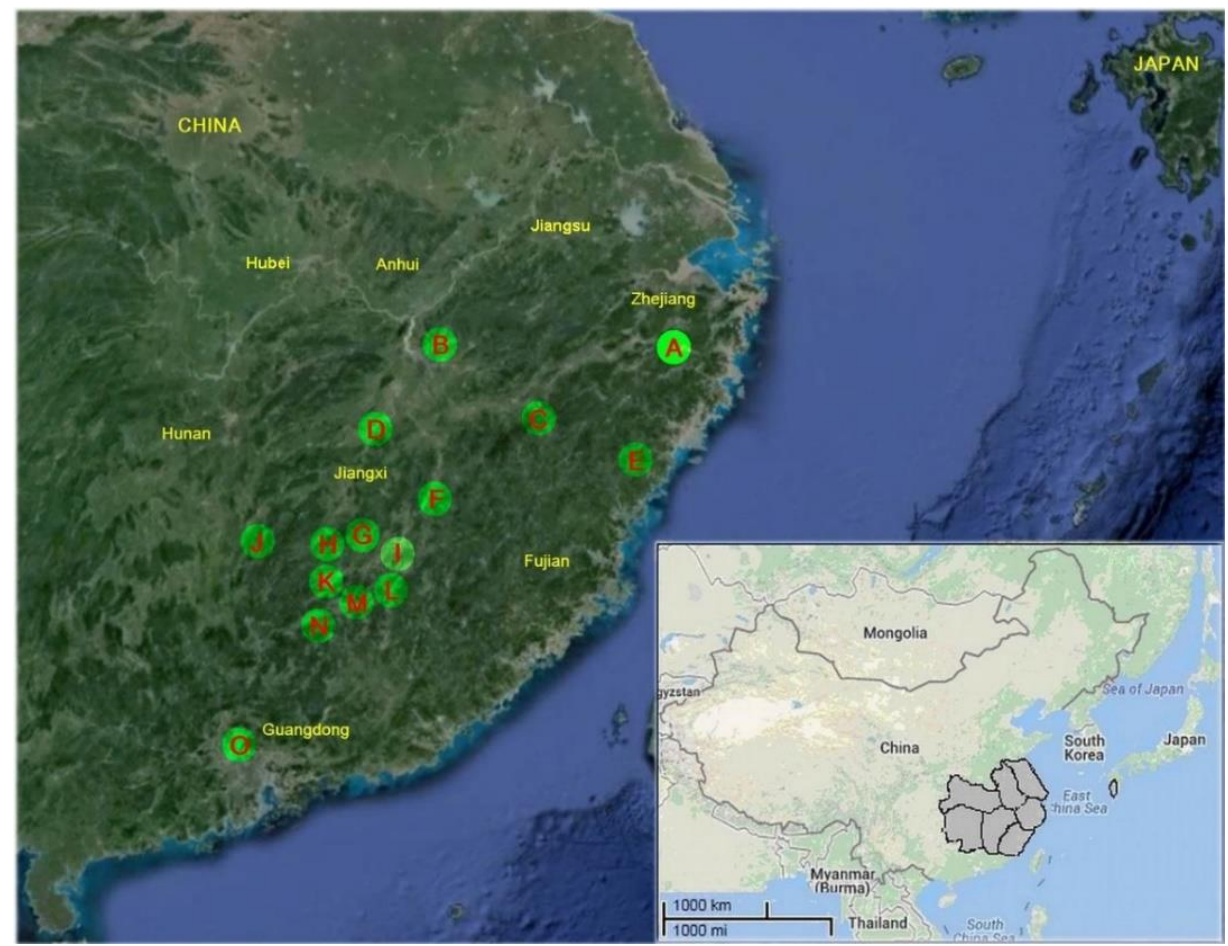

Figure 1. The distribution of Monochasma savatieri in East Asia. Areas in grey in the lower right side represent the $M$. savatieri distribution range according to YAMAZAKI (1993) and HONG \& al. (1998). Green points with red uppercase letters show the distribution areas of M. savatieri in Southeast China based on this study. A: Pan'an $\left(29^{\circ} 40^{\prime} \mathrm{N} 120^{\circ} 27^{\prime} \mathrm{E}\right)$; B: Boyang $\left(29^{\circ} 10^{\prime} \mathrm{N} 116^{\circ} 42^{\prime} \mathrm{E}\right)$; C: Wuyishan $\left(27^{\circ} 51^{\prime} \mathrm{N} 118^{\circ} 2^{\prime} \mathrm{E}\right)$; D: Yongfeng $\left(27^{\circ} 25^{\prime} \mathrm{N} 115^{\circ} 27^{\prime} \mathrm{E}\right)$ (transplant location); E: Zherong $\left(27^{\circ} 21^{\prime} \mathrm{N}\right.$ $\left.119^{\circ} 56^{\prime} \mathrm{E}\right)$; F: Shicheng $\left(26^{\circ} 33^{\prime} \mathrm{N} 116^{\circ} 24^{\prime} \mathrm{E}\right)$; G: Yudu $\left(25^{\circ} 57^{\prime} \mathrm{N} 115^{\circ} 24^{\prime} \mathrm{E}\right)$; H: Ganxian $\left(25^{\circ} 54^{\prime} \mathrm{N}\right.$ $\left.114^{\circ} 59^{\prime} \mathrm{E}\right)$; I: Huichang $\left(25^{\circ} 37^{\prime} \mathrm{N} 115^{\circ} 47^{\prime} \mathrm{E}\right)$; J: Rucheng $\left(25^{\circ} 38^{\prime} \mathrm{N} 113^{\circ} 39^{\prime} \mathrm{E}\right)$; K: Anyuan $\left(25^{\circ} 14^{\prime} \mathrm{N}\right.$ $\left.115^{\circ} 25^{\prime} \mathrm{E}\right)$; L: Wuping $\left(25^{\circ} 11^{\prime} \mathrm{N} 116^{\circ} 8^{\prime} \mathrm{E}\right)$; M: Xunwu $\left(25^{\circ} 30^{\prime} \mathrm{N} 115^{\circ} 38^{\prime} \mathrm{E}\right)$; N: Xinfeng $\left(25^{\circ} 05^{\prime} \mathrm{N}\right.$ $\left.114^{\circ} 56 \mathrm{E}\right)$; O: South China Botanical Garden $\left(23^{\circ} 10^{\prime} \mathrm{N} 113^{\circ} 21^{\prime} \mathrm{E}\right)$.

\section{Seed germination tests}

M. savatieri seeds for three germination tests were collected from Yongfeng County in Jiangxi province (Figure 1D) in May, 2011-2013. All seeds were surface sterilized with $0.5 \%$ mercuric chloride for $3 \mathrm{~min}$ then rinsed in distilled water three times. In test 1 (light and PGRs), seeds were stored in a refrigerator $\left(5^{\circ} \mathrm{C}\right)$ for two weeks, and then germinated in Petri dishes on filter paper soaked for $24 \mathrm{~h}$ in distilled water, $500 \mu \mathrm{M} \mathrm{GA}_{3}, 500 \mu \mathrm{M} 6$ - 
benzyladenine (BA) or $500 \mu \mathrm{M}$ indole-3-acetic acid (IAA). Dishes were transferred to a light or dark culture room. In test 2 (storage temperature and duration), seeds were stored in a 25 $\pm 2{ }^{\circ} \mathrm{C}$ culture room or in a refrigerator $\left(5^{\circ} \mathrm{C}\right)$ for one month, six months, one year and two years, and then germinated on Petri dishes with moist filter paper in a culture room at $25 \pm 2$ ${ }^{\circ} \mathrm{C}$ in the dark by covering with a black cloth.

\section{TTC test for assessing seed viability}

The triphenyltetrazolium chloride (TTC) test was conducted to assess seed viability [PETERS, 2000]. Seeds were stored in a refrigerator $\left(5^{\circ} \mathrm{C}\right)$ for one week, one month, one year or two years, and then placed on Petri dishes (100 seeds/dish) with a single sheet of filter paper. Seeds were soaked in $0.5 \%$ TTC solution for $24 \mathrm{~h}$ and incubated in a growth chamber at $25{ }^{\circ} \mathrm{C}$ under a $12-\mathrm{h}$ photoperiod at a photosynthetic photon flux density of $50 \mu \mathrm{mol} \mathrm{m} \mathrm{m}^{-2} \mathrm{~s}^{-1}$. TTC staining was observed under a stereoscope (Olympus SZX16) at 10-20X magnification. Seeds stained red were considered to be viable while white seeds were unviable (Figure 2E). Each treatment was replicated four times in separate Petri dishes.

\section{Statistical analyses}

A completely randomized design was applied for seed germination experiments. Germination percentage was calculated as: (number of germinated seeds/total number of seeds) $\times 100 \%$. Survival percentage was calculated as: (number of surviving plantlets/total number of transplanted seedlings) $\times 100 \%$. The normal distribution of data was confirmed before performing analysis of variance (ANOVA). Two-way ANOVA was performed using SPSS version 13.0 (SPSS Inc., Chicago, USA) for Microsoft Windows, and means were considered to be significantly different from each other by the Least Significant Difference (LSD) test at $P \leq 0.05$.

\section{Seedling development and field transplantation}

A total of 2000 M. savatieri seeds were collected from Yongfeng county, Jiangxi province (Figure 1D) in May, 2013, stored in a refrigerator $\left(5^{\circ} \mathrm{C}\right)$, then germinated in December 2013. Seeds were divided into two parts spread evenly on one plate filled with vermiculite and one tray filled with a mixture of peat and sand $(1: 1, \mathrm{v} / \mathrm{v})$, respectively. Plates and trays were kept in a moist environment in an open greenhouse, and wrapped in $4 \mathrm{~m}^{2}$ of shade net, which reduced natural sunlight by $95 \%$. After one month, seedlings in the cotyledonary stage about $1 \mathrm{~cm}$ tall were transferred to paper cups $4.5 \mathrm{~cm}$ high and $4.5 \mathrm{~cm}$ in diameter filled with loess. Moss (Hypnum plumaeforme Wilson), covering about one quarter of the paper cup's surface area and with the objective of retaining moisture, was placed on the surface of the loess with forceps while 1-4 seedlings were placed gently on top of the moss [ZHANG \& al. 2015]. Cups were maintained in a moist and shaded environment (with a black net) for one month and then kept in an open greenhouse for three months at ambient temperature $\left(10-20^{\circ} \mathrm{C}\right)$. In April 2014, after seedlings grew to 2-3 cm in height and developed to the euphyllous stage with 3-4 leaves, 100 cups with about 200 seedlings were transported to Yongfeng county in Jiangxi province (Figure 1D), which is a natural habitat of M. savatieri. The four-month-old seedlings, including the loess from the cups, were transferred to small holes ( $5 \mathrm{~cm}$ deep and $5 \mathrm{~cm}$ wide) together with a suitable host plant Gardenia jasminoides $\mathrm{J}$. Ellis (a good host shrub with an extensive root system) at a distance of $20-40 \mathrm{~cm}$ from the host plant stem [ZHANG \& al. 2015]. Soil was initially moistened then watered occasionally. After 8 months, seedling growth and survival percentage were assessed. 


\section{Results}

\section{Distribution of wild resources}

Most M. savatieri plant populations discovered were sporadically distributed in Jiangxi province but were also distributed in other provinces of Southeast China, albeit in fewer numbers. The existing distribution range of $M$. savatieri is from $25^{\circ} 03^{\prime}-29^{\circ} 12^{\prime} \mathrm{N}$ to $113^{\circ} 39^{\prime}-120^{\circ} 27^{\prime} \mathrm{E}$, based on our survey. Growth locations were typified by hills, including in Jiangxi, Fujian, Zhejiang and Hunan. Our assessment indicates that M. savatieri is distributed between the northernmost points of Pan'an, Zhejiang province $\left(29^{\circ} 40^{\prime} \mathrm{N}\right.$ $\left.120^{\circ} 27^{\prime} \mathrm{E}\right)$ and Boyang, Jiangxi province $\left(29^{\circ} 10^{\prime} \mathrm{N} 116^{\circ} 42^{\prime} \mathrm{E}\right.$ ) (Figure 1A, 1B) and the southernmost point of Xinfeng County, Jiangxi province $\left(25^{\circ} 05^{\prime} \mathrm{N} 114^{\circ} 56^{\prime} \mathrm{E}\right)$ (Figure $\left.1 \mathrm{~N}\right)$. The dominant soil types are loess or red earth. Vegetation consists mostly of sparse grasses and shrubs in the center of Jiangxi province (Table 1).

Table 1. Vegetation growing around Monochasma savatieri

\begin{tabular}{|c|c|c|c|}
\hline Species & Family & Habit & Resource \\
\hline Hypnum plumaeforme Will. & Hypnaceae & moss & relatively abundant \\
\hline Funaria hygrometrica Sibth. & Funariaceae & moss & relatively abundant \\
\hline Camellia oleifera Abel. & Theaceae & shrub & abundant \\
\hline Symplocos chinensis (Lour.) Druce & Symplocaceae & shrub & relatively abundant \\
\hline Polygala japonica Houtt. & Polygalaceae & forb & abundant \\
\hline Vitex negundo var. cannabifolia Siebold \& Zucc. & Verbenaceae & shrub & relatively abundant \\
\hline Stimpsonia chamaedryoides Wright ex A. Gray & Primulaceae & forb & abundant \\
\hline Toxicodendron succedaneum (Linn.) O. Kuntze & Anacardiaceae & shrub & infrequent \\
\hline Berchemia floribunda (Wall.) Brongn. & Rhamnaceae & woody climber & abundant \\
\hline Wikstroemia indica (L.) C. A. Mey & Thymelaeaceae & small shrub & abundant \\
\hline Glochidion puberum (L.) Hutch. & Euphorbiaceae & small shrub & abundant \\
\hline Lagerstroemia indica $\mathrm{L}$. & Lythraceae & shrub & abundant \\
\hline Lespedeza formosa (Vog.) Koehne & Fabaceae & shrub & relatively abundant \\
\hline Galactia tenuiflora (Klein ex Willd.) Wight et Arn. & Fabaceae & herbaceous climber & infrequent \\
\hline Gardenia jasminoides Ellis & Rubiaceae & shrub & abundant \\
\hline Serissa serissoides (DC.) Druce & Rubiaceae & small shrub & relatively abundant \\
\hline Hedyotis acutangula Champ. ex Benth. & Rubiaceae & forb & infrequent \\
\hline Lindera aggregata (Sims) Kosterm. & Lauraceae & shrub & infrequent \\
\hline Salvia plebeia $\mathrm{R}$. Br. & Lamiaceae & forb & abundant \\
\hline Scutellaria indica $\mathrm{L}$. & Lamiaceae & forb & infrequent \\
\hline Ixeridium chinense (Thunb.) Tzvel. & Asteraceae & forb & infrequent \\
\hline Solidago decurrens Lour. & Asteraceae & forb & infrequent \\
\hline Eupatorium chinense Linn. & Asteraceae & forb & relatively abundant \\
\hline Gerbera anandria (Linn.) Sch.-Bip. & Asteraceae & forb & infrequent \\
\hline Liquidambar formosana Hance & Hamamelidaceae & tree & infrequent \\
\hline Loropetalum chinense (R. Br.) Oliv. & Hamamelidaceae & shrub & relatively abundant \\
\hline Smilax glabra Roxb. & Smilacaceae & woody climber & infrequent \\
\hline Smilax chinense L. & Smilacaceae & woody climber & infrequent \\
\hline Crataegus cuneata Sieb. et Zucc. & Rosaceae & shrub & infrequent \\
\hline Rubus parvifolius L. & Rosaceae & woody climber & abundant \\
\hline Potentilla discolor Bunge & Rosaceae & herbaceous climber & abundant \\
\hline Rosa cymosa Tratt. & Rosaceae & woody climber & relative abundant \\
\hline Rhaphiolepis indica (L.) Lindl. ex Ker & Rosaceae & shrub & infrequent \\
\hline Imperata cylindrica Linn. Beauv. & Poaceae & grass & relatively abundant \\
\hline Pogonatherum crinitum (Thunb.) Kunth & Poaceae & grass & common \\
\hline
\end{tabular}




\section{Natural growth and vernalization test}

M. savatieri usually grows as a shoot cluster, which may arise from the simultaneous development of multiple seedlings from independent seeds arising from a single capsule, or from one seedling because roots can develop underground adventitious shoots that sprout. These shoots can grow to as high as $20-30 \mathrm{~cm}$, one cluster usually needing 3-5 years to reach this height. In the southernmost point (Figure 1N), M. savatieri usually flowers annually in March to April and in the northernmost point (Figure 1A, 1B), it flowers annually in April to May. A single shoot can develop 3-9 flowers and one large shoot cluster can develop several dozen flowers, which flower acropetally on axillary stalks (Figure 2A). Flowers are whitepink and about $3 \mathrm{~cm}$ long (Figure 2A) and can be pollinated by both small insects and wind. A single shoot cluster can last for one month during flowering and fruit dehiscence stages. The fruits open upwardly and remain attached to the plant (Figure 2A). Thus, seeds are retained in the capsule, avoiding decay in soil or predation by insects, and tend to be discharged from the capsule after a storm. In normal conditions, capsules drop naturally to the ground usually between May and June. In east China, March to May is usually the wet and rainy season while storms are typical in May to August. These periods provide a wet environment for seed germination and seedling development when seedlings usually grow on moss (Figure 2B), which allows moisture to be retained. Seeds are spindle-shaped and very small, $0.7 \mathrm{~mm}$ long and $0.4 \mathrm{~mm}$ wide (Figure 2A, 2F), and 10,000-seed weight is only $0.8 \mathrm{~g}$. Seed germination and development of $1-\mathrm{cm}$ high plantlets needs half a year to complete. Seedlings 3-5 cm high growing in the wild in May were derived from the previous year's seed bank (Figure 2B). During the seedling stage, some shrubs and forbs were assumed as host plants (Table 1). The matured plants usually grow rapidly in spring (3-4 cm long each month) and autumn but slowly in summer and winter (0-1 cm long each month). In the south and centre of Jiangxi province, plants can survive year round. However, in winter in northern Jiangxi province, after above-ground shoots die-back while underground roots remain alive, new shoots sprout from its roots in the next spring. Plants that were brought back to Guangzhou (Figure 1O), Guangdong province where temperatures often exceed $35{ }^{\circ} \mathrm{C}$ in summer, could grow well in winter and spring, but not in summer. In Guangzhou, M. savatieri plants collected from Pan'an on October 25, 2010 and November 5, 2011 could not flower when planted in SCBG, Guangzhou (Figure 2C), while those collected from Zherong on March 16, 2011, from Shihan on December 20, 2012 and from Tengtian on November 29, 2012 were able to flower in February of the next year (Figure 2D). 
Yulu CHEN \& al.
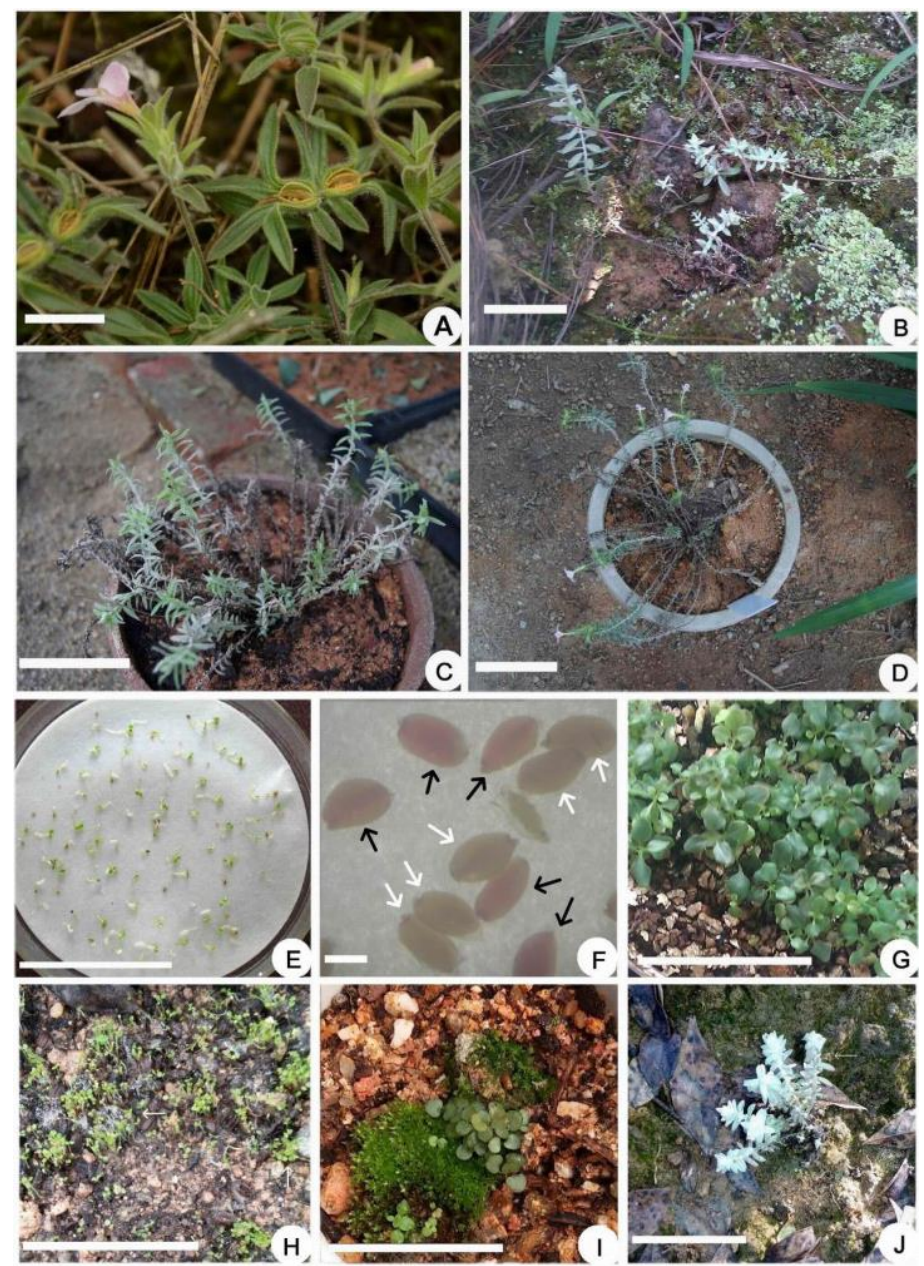

Figure 2. Flowering, fruits, seedling investigation, vernalization test, seed germination tests, seedling cultivation and transplantation of Monochasma savatieri. (A) Both flowers grew acropetally where axillary mature fruits gathered on the same plant. Flowering was acropetal or axillary and fruit opened upwardly and remained attached to the plant; $b a r=1 \mathrm{~cm}$. (B) One-year-old plantlets found in the wild at Yudou in May 2013 (Figure 1G); bar $=2 \mathrm{~cm}$. (C) A plant brought back from Pan'an (Zhejiang province) on October 25, 2010 and potted, but did not flower in February, 2011 in Guangzhou; bar = 5 $\mathrm{cm}$. (D) A plant brought back from Tengtian (Jiangxi province) in December 20, 2012 and flowered in February, 2013 in Guangzhou; bar $=5 \mathrm{~cm}$. (E) Seed germination test with $500 \mu \mathrm{M} \mathrm{GA}_{3}$ in the light after culture on a Petri dish with a single sheet of filter paper for 28 days; bar $=5 \mathrm{~cm}$. (F) Seed viability as assessed by the TTC staining test; black arrows indicate seeds stained red (viable) while white arrows indicate non-stained seeds (unviable); bar $=0.5 \mathrm{~mm}$. (G) Seeds, after pretreatment with $600 \mu \mathrm{M} \mathrm{GA}_{3}$, germinated in vermiculite and developed into seedlings at the euphyllous stage after 4 months; bar $=5$ $\mathrm{cm}$. (H) Seeds were pretreated with $800 \mu \mathrm{M} \mathrm{GA}_{3}$ and germinated and developed into seedlings at the cotyledonary stage (white arrow) on peat and loess $(1: 1, \mathrm{v} / \mathrm{v})$ after culture for one month; bar $=5 \mathrm{~cm}$. (I) Seedlings at the cotyledonary stage were transferred to paper cups that contained loess and moss (Hypnum plumaeforme) after culture for 4 months; bar $=2.5 \mathrm{~cm}$. (J) Seedlings grew well (white arrows) after transplanting with Gardenia jasminoides, a shrub, for 8 months; bar $=5 \mathrm{~cm}$. 


\section{Effects of light and plant growth regulators on seed germination}

When cultured in light, seed germination percentage following exposure to $500 \mu \mathrm{M}$ $\mathrm{GA}_{3}$ was about $80 \%$ within 28 days (Figure 3 ). However, after exposure to BA and IAA, seed germination percentage was only about $50 \%$ within 28 days. This was the same level as the control but significantly lower than the $\mathrm{GA}_{3}$ treatment (Figure 3). In the dark, seed germination percentage after treatment with $500 \mu \mathrm{M} \mathrm{GA} 3$ was only $38 \%$, which was significantly lower than in light culture $(80 \%)$. After exposure to BA and IAA, seed germination percentage was only $3-4 \%$, which was the same level as the control (Figure 3), but significantly lower than the $\mathrm{GA}_{3}$ treatment.

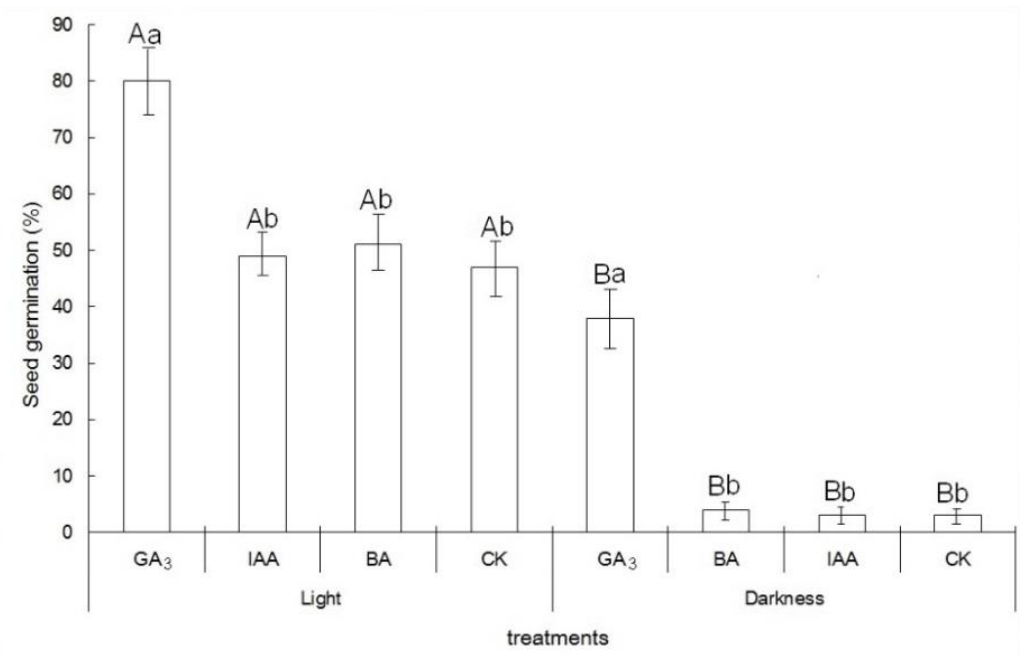

Figure 3. Monochasma savatieri seed germination in response to treatments with light and plant growth regulators. The same lowercase letters are not significantly different for the same light (or dark) treatment while the same uppercase letters are not significantly different for the same plant growth regulator treatment (LSD test; $P \leq 0.05$ ).

\section{Effects of storage temperature and duration on seed germination}

Both the germination percentage of $M$. savatieri seeds stored at $25^{\circ} \mathrm{C}$ or at $5{ }^{\circ} \mathrm{C}$ was about $80 \%$, respectively. The germination percentage of seeds stored for six months decreased to $45 \%$ at $25{ }^{\circ} \mathrm{C}$ and to $76 \%$ at $5{ }^{\circ} \mathrm{C}$. The germination percentage of seeds stored for one year decreased to $18 \%$ at $25^{\circ} \mathrm{C}$ and to $66 \%$ at $5{ }^{\circ} \mathrm{C}$. After two years, seed germination percentage decreased to $1 \%$ at $25^{\circ} \mathrm{C}$ and to $45 \%$ at $5{ }^{\circ} \mathrm{C}$ (Figure 4 ).

\section{Tetrazolium tests to assess seed viability}

TTC staining percentage was $86 \%, 47 \%, 17 \%$ and $3 \%$ for seeds stored at $25{ }^{\circ} \mathrm{C}$ for one month, six months, one year and two years, and $85 \%, 74 \%, 65 \%$ (Figure $2 \mathrm{~F}$ ) and $43 \%$ (Figure 5), respectively for seed stored at $5{ }^{\circ} \mathrm{C}$. These results almost coincided with the seed germination values. 


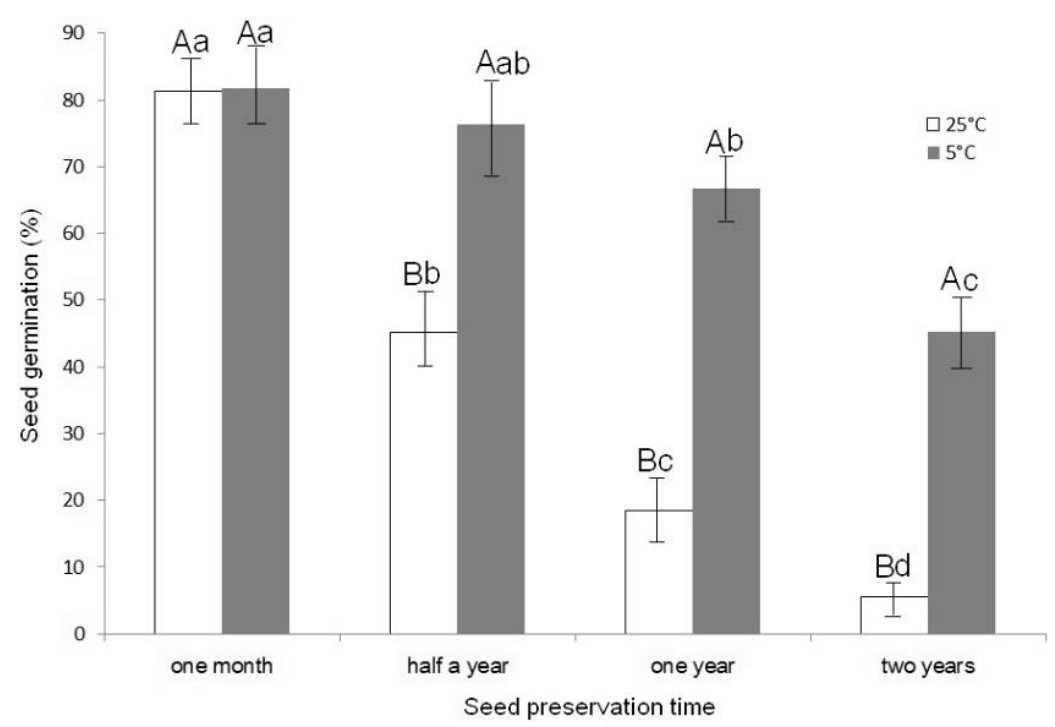

Figure 4. Monochasma savatieri seed germination at two temperatures and four storage periods. The same lowercase letters are not significantly different at the same storage temperature $\left(5^{\circ} \mathrm{C}\right.$ or $\left.25^{\circ} \mathrm{C}\right)$ and the same uppercase letters are not significantly different at the same seed storage period (LSD test; $P \leq 0.05)$.

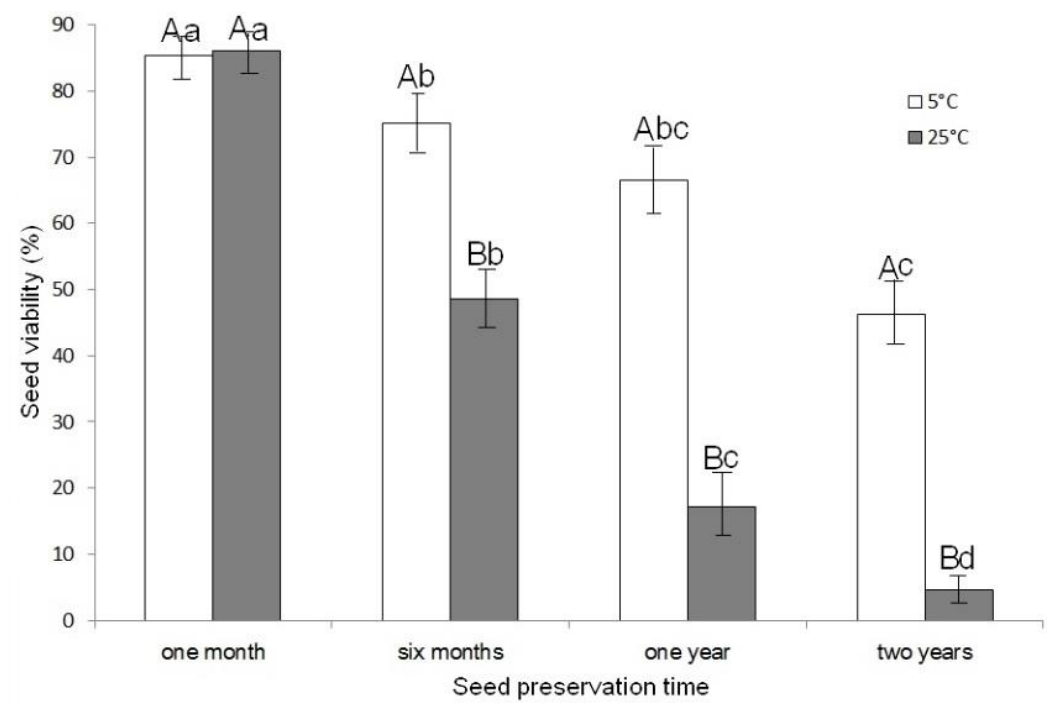

Figure 5. Effects of storage temperature and duration on Monochasma savatieri seed viability. The same lowercase letters are not significantly different at the same seed storage temperature and the same uppercase letters are not significantly different at the same storage period (LSD test; $P \leq 0.05$ ). 


\section{Seedling development and field transplantation}

Seeds germinated on the surface of vermiculite, peat and loess within two weeks, exceeding $80 \%$ (Figure $2 \mathrm{G}, 2 \mathrm{H}$ ) after treatment with $600 \mu \mathrm{M} \mathrm{GA}_{3}$. It is interesting to note that seedlings without an attached host grew well up until four months of age. Under dim light and wet conditions, seedlings grew slowly and the cotyledonary stage lasted for at least 2-3 months before developing the first true leaf (Figure 2I). During the cotyledonary stage, plantlets grew very slowly, possibly due to the lack of a suitable host and nutrition. After culture for another four months, seedlings could grow to $4-5 \mathrm{~cm}$ in height. After interplanting with G. jasminoides, 33 M. savatieri plantlets survived (23.3\%) to 8 months (Figure 2J).

\section{Discussion}

Southeast China and Kyushu (Amakusa Islands, Japan) have a subtropical monsoon climate and hilly landform that allows $M$. savatieri to grow. Special biological requirements of $M$. savatieri such as the requirement for low temperature vernalization, moderate temperature for growth or hemiparasitism on host plant roots presumably result in special habitat requirements, which may account for its limited distribution. Since M. savatieri is distributed naturally in east China, including Jiangxi, Fujian, and Zhejiang provinces but not in South China (Guangzhou, Guangdong province), we believe that vernalization temperature is likely to be at most $-6{ }^{\circ} \mathrm{C}$ because the lowest temperature is $-6{ }^{\circ} \mathrm{C}$ at the southernmost point (Xinfeng County, Jiangxi).

Under natural conditions, a single flowering shoot cluster lasts one month and seeds, which also take one month to mature, also survive for an additional month. In the center of Jiangxi province, M. savatieri flowers from April to May and produces seeds in May. The capsules dehisce when they mature, releasing seeds that may germinate if they encounter ideal conditions. During this period, it often rains, which favors seed germination and seedling development. From our results, seed germination was highest within one month but after one year, seed germination decreased to $20 \%$. In the rainy season, the soil is moist and shaded and moss grows easily, providing a suitable environment for seed germination and seedling growth (Figure 1B). As seedlings mature, M. savatieri favors a sunny environment and higher terrain that does not easily become waterlogged. The growth conditions in the same area can change between seasons and may face biotic and abiotic stresses, which may explain the low natural sexual reproduction of M. savatieri. Artificial seed storage and proper sowing conditions thus need to be considered.

Our studies also showed that light and $\mathrm{GA}_{3}$ pretreatment enhanced seed germination, which indicates that $M$. savatieri seeds favor light. Moreover, under natural conditions, after seeds drop to the ground and encounter suitable conditions, natural light can enhance germination. Light usually acts synergistically with $\mathrm{GA}_{3}$ to enhance seed germination [TOYOMASU \& al. 1998; YAMAGUCHI \& KAMIYA, 2001; SEO \& al. 2006]. Sometimes, seed remains dormant due to the presence of abscisic acid (ABA) while $\mathrm{GA}_{3}$ can counter the effects of ABA [SHINOMURA \& al. 1994; LOVEGROVE \& HOOLEY, 2000; NAMBARA \& MARION-POLL, 2005]. The physiological dormancy of $M$. savatieri seeds might be broken by $\mathrm{GA}_{3}$ or low temperature [YANG, 2009]. Even in the absence of $\mathrm{GA}_{3}$ treatment, seed germination was high (> 60\%), indicating that seeds broke dormancy in the first two weeks. At this stage, $\mathrm{GA}_{3}$ and light could enhance seed germination. After one month, most seeds had broken dormancy, and even in the absence of $\mathrm{GA}_{3}$, seed germination was high (> $80 \%$ ). Seed germination and seed viability declined after one month. This careful fine-scale 
understanding of the balance between these two parameters is necessary to accurately time artificial seed germination.

In its natural environment, all M. savatieri seeds germinate on moss (Hypnum plumaeforme or Funaria hygrometrica) [ZHANG \& al. 2015]. This moss might not only supply a moist environment and nutrients for seed germination and seedling growth of some species [REN \& al. 2010], but might also secrete phytohormones to enhance seed germination [RESKI, 2006; VON SCHWARTZENBERG, 2006].

The wild habitats of $M$. savatieri are shrinking, and are under rapid threat and decline. By understanding the growth habits of this plant in the wild, including its complex hemiparasitism and the need for host plants to develop haustoria [ZHANG \& al. 2015], as well as its vernalization and flowering requirements, seed can be effectively produced, allowing for artificial sexual reproduction of $M$. savatieri, thus providing a robust protocol that would buffer the extinction of this species in the face of rapid urbanization and habitat destruction in China. The protocol in this study is thus useful in practical terms and is also socially important. A transplantation test in Guangzhou indicated that M. savatieri plants need a period of vernalization, i.e., a period of low winter temperature, to induce floral bud differentiation in order to flower and produce seeds. Thus, this species is not suitably cultivated in South China where winters are short, not allowing plants to flower in spring. Is then culture of the species suitable in North China? Here, the answer is also negative since too low a temperature $\left(<-20^{\circ} \mathrm{C}\right)$ in winter may kill the whole plant including above - and below - ground parts. M. savatieri is confined to small parts of Southeast China and Japan [YAMAZAKI, 1993; HONG \& al. 1998]. What confined its distribution, and how? This study shows that characteristic $M$. savatieri habitats include sunny slopes of small mountains and hills, rich with grasses and shrubs, that often contain red clay and loess soil. Thus, it can be concluded that $M$. savatieri is sun-loving, grows in acidic soil and prefers to parasitize small herbs and shrubs. Since M. savatieri has strict habitat conditions, it can only grow in limited areas of favorable climatic and geographic environments. Besides, this study also shows that the primary mode of reproduction of $M$. savatieri is by seeds, which is not very efficient because of seed dormancy and a requirement for the early establishment of seedling parasitism. After shedding from plants, seeds may take several months to germinate. This may cause a loss in seedling vigour. Seedlings that form successfully also risk untimely parasitism, which is vital to their survival, especially in dry soil. Thus, certain environmental conditions involving water, temperature, or host roots in the vicinity of seedlings must prevail.

Our study indicates that transplanted $M$. savatieri seedlings could survive in the field when planted with a suitable host. Thus, artificial propagation and reintroduction of this medicinal plant back into the wild is possible and serves as a feasible method for the ecorehabilitation of areas that have been depleted of natural stocks, or that lack genetic heterogeneity.

\section{Conclusions}

In this study, the distribution, climate, soil type, flowering and seed production, cooccurring vegetation, pollinators, ecology, seed germination, seedling establishment, and reintroduction of the traditional Chinese hemiparasitic medicinal herb, Monochasma savatieri, were investigated. Seed germination was enhanced by gibberellic acid and low temperature storage, which benefitted and sustained seed viability. Seedling development 
and subsequent transplantation to the field resulted in a low survival percentage, indicating that much more work is needed on this species before cultivation.

\section{Acknowledgments and conflicts of interest}

This work was supported by the National Natural Science Foundation of China (Grant Nos. 31100498,31270720 and 30972295). The authors declare no conflicts of interest.

\section{Notes on contributors}

Yulu CHEN and Menghan ZHANG are postgraduate students in a master's degree. Both have graduated from South China Botanical Garden, Chinese Aademy of Sciences, and have studied Monochasma savatieri for five years.

Dr. Jaime A. TEIXEIRA DA SILVA is a plant biologist and biotechnologist.

Prof. Guohua MA is a plant biologist whose work focuses on the biotechnology of semiparasitic plants.

\section{References}

BENNETT J. R. \& MATHEWS S. 2006. Phylogeny of the parasitic plant family Orobanchaceae inferred from phytochrome A. American Journal of Botany. 93: 1039-1051. https://doi.org/10.3732/ajb.93.7.1039

ENVIRONMENT AGENCY OF JAPAN. 2000. Threatened wildlife of Japan, Red data book. In: Environmental Agency of Japan (Eds.) Vascular Plants (Ed. 2), Japan Wildlife Research Center, Tokyo, Japan: pp. 660.

HONG D., YANG H., JIN C. \& HOLMGREN N. H. 1998. Scrophulariaceae. In: WU Z. Y. \& RAVEN P. H. (Eds). Flora of China. Vol. 18, Science Press and Missouri Botanical Garden Press, Beijing, China, pp. 211-212.

HONG D. Y. 1986. A new genus of Scrophulariaceae from Xizang, China. Acta Phytotaxonomica Sinica. 24: 139-142.

KOHDA H., TANAKA S., YAMAOKA Y., YAHARA S., NOHARA T., TANIMOTO T. \& TANAKA A. 1989. Studies on lens-aldose-reductase inhibitor in medicinal plants. 2. Active constituents of Monochasma savatieri Franch ex Maxim. Chemical \& Pharmaceutical Bulletin. 37: 3153-3154. https://doi.org/10.1248/cpb.37.3153

LI M., SHI M. F., LIU Y. L., XU Q. M. \& YANG S. L. 2012. Phenylethanoid glycosides from Monochasma savatieri and their anticomplement activity through the classical pathway. Planta Medica. 78: 1381-1386. https://doi.org/10.1055/s-0032-1314982

LIU Y. L., HE W. J., MO L., SHI M. F., ZHU Y. Y., PAN S., LI X. R., XU Q. M \& YANG S. L. 2013. Antimicrobial, anti-inflammatory activities and toxicology of phenylethanoid glycosides from Monochasma savatieri Franch ex Maxim. Journal of Ethnopharmacology. 149: 431-437. https://doi.org/10.1016/jjep2013.06.042

LOVEGROVE A. \& HOOLEY R. 2000. Gibberellin and abscisic acid signaling in aleurone. Trends in Plant Science. 5: 102-110. https://doi.org/10.1016/s1360-1385(00)01571-5

NAMBARA E. \& MARION-POLL A. 2005. Abscisic acid biosynthesis and catabolism. Annual Review of Plant Biology. 56: 165-185. https://doi.org/10.1146/annurev.arplant.56.032604.144046

PETERS J. 2000. Tetrazolium testing handbook. In: The Handbook on Seed Testing (contribution no. 29). Association of Official Seed Analysts, Lincoln, NE, USA.

REN H., MA G. H., ZHANG Q. M., GUO Q. F., WANG J. \& WANG Z. F. 2010. Moss is a key nurse plant for reintroduction of the endangered herb, Primulina tabacum Hance. Plant Ecology. 209: 313-320. https://doi.org/10.1007/s11258-010-9754-5

RESKI R. 2006. Small molecules on the move: Homeostasis, crosstalk, and molecular action of phytohormones. Plant Biology. 8: 277-280. https://doi.org/10.1055/s-2006-924190

SCHWARTZENBERG V. K. 2006. Moss biology and phytohormones - cytokinins in Physcomitrella. Plant Biology. 8: 382-388. https://doi.org/10.1055/s-2006-923962

SEO M., HANADA A., KUWAHARA A., ENDO A., OKAMOTO M., YAMAUCHI Y., NORTH H., MARIONPOLL A., SUN T. P., KOSHIBA T., KAMIYA Y., YAMAGUCHI S. \& NAMBARA E. 2006. Regulation of hormone metabolism in Arabidopsis seeds: phytochrome regulation of abscisic acid metabolism and abscisic acid regulation of gibberellin metabolism. The Plant Journal. 48: 354-366. https://doi.org/10.1111/j.1365-313X.2006.02881.x 


\section{Yulu CHEN \& al.}

SHINOMURA T., NAGATANI A., CHORY J. \& FURUYA M. 1994. The induction of seed germination in Arabidopsis thaliana is regulated principally by phytochrome B and secondarily by phytochrome A. Plant Physiology. 104: 363-371. https://doi.org/10.2307/4275630

TOYOMASU T., KAWAIDE H., MITSUHASHI W., INOUE Y. \& KAMIYA Y. 1998. Phytochrome regulates gibberellin biosynthesis during germination of photoblastic lettuce seeds. Plant Physiology. 118: 1517 1523. https://doi.org/10.1104/pp.118.4.1517

YAHARA S., NOHARA T., KOHDA H., SHIMOMURA K. \& SATAKE M. 1986. Study on the constituents of Monochasma savatieri Franch ex Maxim. Yakugaku Zasshi (Journal of the Pharmaceutical Society of Japan). 106: 725-728. https://doi.org/10.1248/yakushi1947.106.8_725

YAMAGUCHI S. \& KAMIYA Y. 2001. Gibberellins and light-stimulated seed germination. The Journal of Plant Growth Regulation. 20: 369-376. https://doi.org/org/10.1007/s003440010035

YAMAZAKI T. 1993. Scorphulariaceae. In: IWATSUKI K., YAMAZAKI T., BUFFORD D. E. \& OHBA H. (Eds). Flora of Japan. Vol. a, Smithsonian Institution Press, Kodansha, Tokyo, Japan, pp. 358-359.

YANG Y. Z. 2009. Characteristic on dormancy and germination of Monochasma savatieri Franch. ex Maxim seeds. Seed. 28: 82-84 (in Chinese). https://doi.org/1001-4705(2009)03-0082-03

ZHANG M. H., OUYANG Y., HUANG Z. G., TEIXEIRA DA SILVA J. A. \& MA G. H. 2015. The biology and haustorial anatomy of semi-parasitic Monochasma savatieri Franch. ex Maxim. Plant Growth Regulation. 75: 473-481. https://doi.org/10.1007/s10725-014-0010-1

ZHU C. W., ZHOU X. J., ZHAO P., CHEN L. X. \& HE J. H. 2011. Onset of East Asian subtropical summer monsoon and rainy season in China. Science China Earth Sciences. 54: 1845-1856. https://doi.org/10.1007/s11430-011-4284-0

\section{How to cite this article:}

CHEN Y., ZHANG M., TEIXEIRA DA SILVA J. A. \& MA G. H. 2019. Seed germination, seedling establishment and reintroduction into the wild of the hemiparasitic medicinal plant Monochasma savatieri. J. Plant Develop. 26: 45-57. https://doi.org/10.33628/jpd.2019.26.1.45 